Volume 9, No.4, July - August 2020

International Journal of Advanced Trends in Computer Science and Engineering

Available Online at http://www.warse.org/IJATCSE/static/pdf/file/ijatcse304942020.pdf

https://doi.org/10.30534/ijatcse/2020/304942020

\title{
Evaluating e-Learning Google Classroom tools for Computer Science Subjects during COVID-19 Pandemic
}

\author{
Nurul Akhmal Mohd Zulkefli ${ }^{1}$, Haslinda Hashim ${ }^{2}$, Syerina Syahrin ${ }^{3}$ \\ ${ }^{1}$ Dhofar University, Oman, nzulkefli@du.edu.om \\ ${ }^{2}$ Universiti Pendidikan Sultan Idris, Malaysia, haslinda@ fskik.upsi.edu.my \\ ${ }^{3}$ Dhofar University, Oman, sysyahrin@du.edu.om
}

\begin{abstract}
COVID-19 pandemic has affected teaching and learning around the world. As a result, schools and higher learning institutions use the e-learning platform to replace face-to-face teaching and learning. In Oman, the government encourages educational institutions to use suitable e-learning platform. This study aims to evaluate the e-learning Google Classroom as a teaching and learning tool during the COVID-19 pandemic. A total of 22 Computer Science students at a higher learning institution in Oman enrolled in Computer Programming, Introduction to Database Management System, Network System, Web Development, Operating System, and Management Information System competed in the study. The questionnaire used implemented from the previous study and sustained the expert's consent. The study was examined using descriptive statistics with regular standard deviation, percentage, frequency, and score. Inferential statistics included Pearson correlation tests. The study attested that the mean level of challenge faced by students in using Google Classroom is 3.71. Meanwhile, the Pearson correlation test found that the significant value was .000 . Therefore, there was a relationship between technical support for the operating system and social presence aspects. Hence, the null hypothesis (H0) was rejected.
\end{abstract}

Key words: E-learning tool, Google Classroom, teaching, and learning, Oman

\section{INTRODUCTION}

This research aims to evaluate the e-Learning tools, which is Google Classroom, as an online learning platform for online education. The result of this research provides a benchmark for implementing online education in institutions in Oman, especially during a pandemic crisis such as COVID-19. As announced by the Ministry of Education in Oman, all schools and higher institutions are suspended until the mid of April of 2020, and the suspension may extend further if the COVID-19 pandemic continues. Researchers are encouraged to contribute their expertise in various fields to search and explore the best solution to cope and overcome the crisis.

This research evaluates the e-learning during the crisis. Even though several institutions provide online learning, there were challenges during the process. To cope with the crisis, a fast, stable, and accurate decision is needed to prevent the interruption of ongoing classes in Oman. Currently, there are not many studies on online education during the pandemic. To develop or implement a new e-learning system and motivate teachers and learners in a short period, e-learning should be effectively used. It is crucial to understand the effectiveness of online education as revealed in this comparative study to help support the teaching and learning for online education in Oman.

Modern pedagogy often goes on par with new technology for education. It is important to identify the requirements or factors that contribute to successful teaching and learning in this modern time. This study contributes to the enhancement of online study in Oman. The objectives and hypotheses of this study are as follow:

I. To evaluate the use Google Classroom at the higher learning institution in Oman in terms of Functionality, Accessibility, Technical, Mobile Design, Privacy, Data Protection and Rights, Social Presence, Cognitive Presence.

II. To identify the interaction of Operating Systems and collaboration in Social Presence.

Ho: There is no significant interaction between

Operating System and collaboration in Social

Presence.

Ha: There is a significant interaction between Operating System and collaboration in Social Presence.

\section{LITERATURE REVIEW}

\subsection{COVID-19 Pandemic}

COVID-19 begins to spread in late December 2019, and it started in Wuhan, China [1]. Since early January 2020, the whole world began to acknowledge the new virus of COVID-19. The world becomes chaotic in January, the number of positive patients is increasing rapidly, and there are no boundaries to protect humans from this virus. China implemented lockdown in Wuhan in February to control the spread of the virus [2].

Within a short period, COVID-19 spread rapidly and affected other countries worldwide. As the virus continued to spread, 
the government in different countries executed Movement Control Order (MCO) and lockdown which affected many sectors as financial, business, tourism, and education [3].

\section{2 e-Learning}

During the early detection of COVID-19, China was the first country to mandate school closures, which involved more than 200 million students. This decision was followed by Japan that announced the closure of schools starting February 27, 2020, while Malaysia from March 18, 2020[4]. Meanwhile, Mongolia, Bahrain, Iraq, San Mongolia closed all schools by the end of February 2020 and many countries in March 2020 [5].The decision on the closure of schools and education institutions significantly impacted teachers and students. The move towards online education may be challenging for developing countries with limited access to the Internet.

The right decision, a practical solution, and excellent teamwork are needed from the teachers, the government, parents, and students. The primary schools and the secondary schools in Malaysia started online learning from March 2020 after the school break. New Zealand also started online teaching after March 26, 2020. Both of the countries started online education within two months of the COVID-19 spread. Critics argue careful planning is needed before the launching of online education. Online learning is not a new phenomenon, especially in higher education institutions[6]. It has been used widely in top institutions Students from anywhere in the world can access online learning at no charge on some universities such as Massachusetts Institute of Technology (MIT). Nowadays, online learning platforms have offered many advanced technologies where educators can teach students in real-time using video conferencing tools such as a Google Meeting, Zoom, and BigBlueButton [7]. Lecturers can share their laptop or computer's screens while teaching the students. Students can also use the video and audio features to communicate in discussions directly or ask the teacher any questions. Besides that, online quizzes and exam platforms are also available. Many teachers also use gamification learning to increase students' understanding of specific topics [8]. These tools support classroom teaching by embedding them onto the online learning platform.

To conduct online learning in an institution either for schools or universities, a well-prepared plan such as practical implementation for teachers to use ICT in teaching must be available because the process of teaching and learning has been exceeding the physical space of a classroom $[9,10]$. Educators need to know the basics of ICT to enable them to use the e-learning system. The institution has to have stable and reliable facilities to manage and support the online learning system. The system's functions include supporting all the uploaded materials and a stable network for accessing the materials during peak time. Many institutions have been using the online learning platform only as a support learning system. Previous studies commented that teachers and students, particularly those in the developing countries, are not familiar with the technologies. Additionally, not all of the institutions are equipped with the requirements for supporting online education. A fast, stable, user-friendly, low-cost online learning system and effectively used in various subjectsis warranted. [11, 12]. During an unexpected crisis such as the COVID-19 pandemic, a reliable solution should be provided based on critical issues of online learning requirements, either functional or non-functional requirements.

Many online learning management systems (LMS), which is also known as Virtual Learning System (VLE), exist such as Google Classroom (in G-Suite) provided by Google, Moodle, Edsby, Blackboard, Docebo and institution's LMS [14]. All of these LMS are well-known and used by many institutions around the world. The challenge for governments, education institutions, and teachers is to seek the right LMS that fits the students' needs.

\subsection{LMS and Google Classroom}

The LMS system implemented at the context of study is Moodle, and the challenges of using Moodle as LMS are addressed in turns. The first challenge encountered was the network connectivity. During the first two weeks of running virtual classrooms, the institution faced network connectivity problem during the peak hours of classes. The second challenge encountered is that the LMS was not prepared to receive a high volume of data of online video teachings. The third challenge is the students' limited access of internet to use the LMS. During the course of study, the majority of the students were not able to participate online due to low internet coverage and limited data. These three factors are the main issues when setting up the virtual classroom on Moodle LMS.

The institution overcame one of the challenges by acquiring the server's storage issues in uploading the teaching materials and teaching videos. The management of the institution negotiated for special arrangement of access to the Internet for students living far from the city. The management of the higher education institution also invested in higher internet capacity with the communication provider.

One of the ways to overcome the challenges encountered when using Moodle is to seek for alternate LMS such as Google Classroom. Google Classroom is a free, stable cloud-based platform. Google is known to many Internet users. The Google software can be used on mobile phone, computers and laptops. In addition to that, Google Classroom is one of the most accessible LMS platforms as it provides a simple interface for teachers and students to use [12]. Google Classroom apps can also be downloaded and installed on the mobile phone. It can be integrated with Google applications (G-Suite) such as Google Drive, Google Docs, Google Form, Google Slides, YouTtube, and other apps [13]. Google education works in a real-time environment. When a teacher or student shares the message in Google Classroom's stream, the students receive the notification in a real-time mode. Google Classroom is also known as a stable platform for server or network. As long as students and teachers have 
access to the Internet, videos and teaching materials are accessed instantaneously. The Google Classroom features include quiz, shared drive (where students and teachers can discuss in a real-time), and rubric for assignments. Other facilities are centralized Grading System and real-time sharing messages. Google Classroom includes links to Google Drive and social repository (e.g. YouTube) for the storage of large capacity files.

Google Classroom is used to support Centred-Based Learning (CBL), Project-based Learning, and Project-based Learning [15]. The organization tools on Google classroom enable teachers to easily manage online classrooms. For this particular investigation, Google Classroom was used in concurrence with Moodle.

\section{RESEARCH METHODOLOGY}

The findings for this study was sought from 22 students utilizing online questionnaire. The purpose of the questionnaire was to seek the students' perspectives of using Google Classroom as part of their online learning. The questionnaire used a four-point nominal scale varying of 1 (not applicable) to 4 (works well). Before the distribution of the questionnaire, an expert evaluated the instrument to assure its validity. To ensure reliability, a pilot study was carried out with 15 students enrolled in computer science subjects at the higher education institution in Oman. The results revealed the Cronbach Alpha was significant at 0.9. All of the data were analyzed with inferential and descriptive statistics.

Based on the survey, the highest number of respondents were the male students at $81.82 \%$, compared to $22.22 \%$ for the female respondents. The distribution of the respondents is illustrated in Figure 1. The online education was fully implemented in March, 2020 during the COVID-19 outbreak. Teachers are required to use online learning tools such as Moodle to compensate for the traditional teaching so that students can continue learning. Figure 2 below shows the interface of Google Classroom for the Introduction to Database and Computer Programming class.The questionnaire was adopted from a rubric for e-learning Tool Evaluation [16] that consists of seven categories as presented in Table 1.In this research, not all of the criteria in the rubric was used to evaluate the Google Classroom e-learning tools such as the Teaching Presence

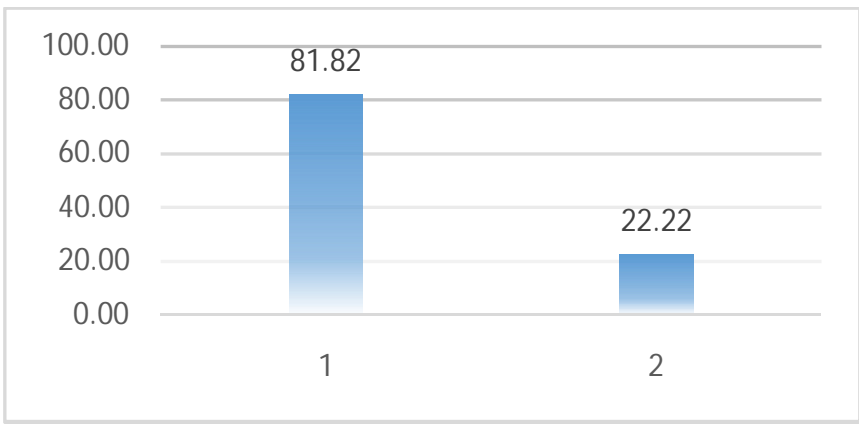

Figure 1:Percentage of respondents between male and female students.

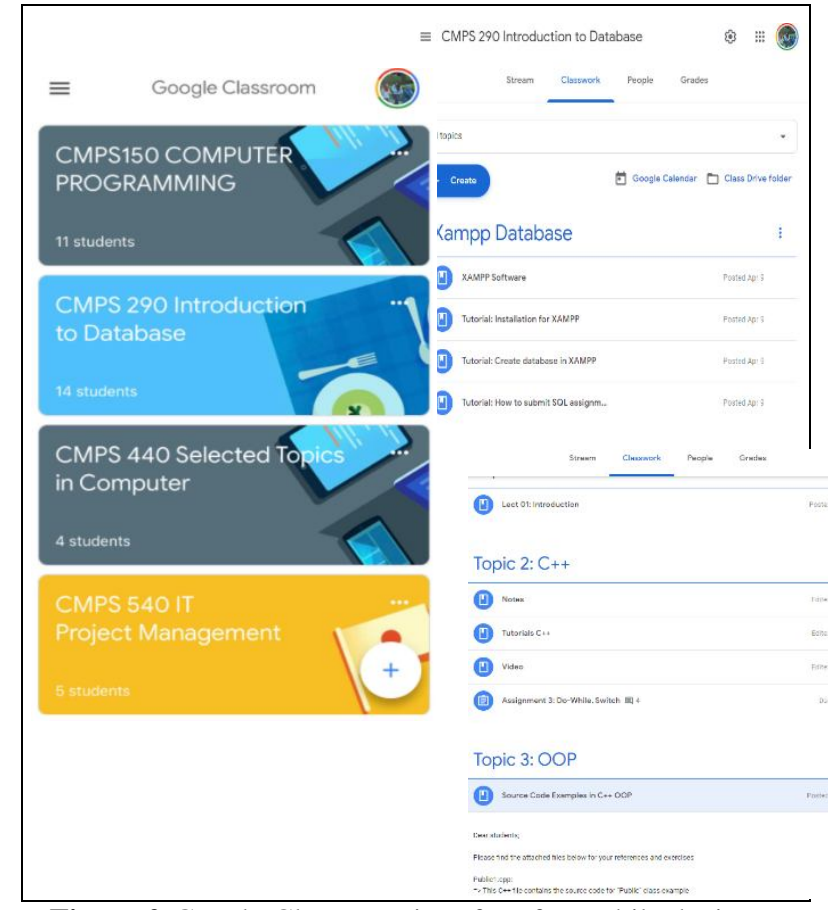

Figure 2:Google Classroom interface for mobile device

Table 1: Rubric for e-learning Tool Evaluation

\begin{tabular}{|c|c|}
\hline Category & Criteria \\
\hline Functionality & $\begin{array}{ll}\text { - } & \text { Scale } \\
\text { - } & \text { Ease of Use } \\
\text { - } & \text { Tech Support / Help Availability } \\
\text { - } & \text { Hypermediality }\end{array}$ \\
\hline Accessibility & $\begin{array}{ll}\text { - } & \text { Accessibility standards } \\
\text { - } & \text { User-focused participation } \\
\text { - } & \text { Required Equipment } \\
\text { - } & \text { Cost of Use }\end{array}$ \\
\hline Technical & $\begin{array}{ll}\text { - } & \text { Integration/ Embedding within a } \\
& \text { Learning Management System (LMS) } \\
\text { - } & \text { Desktop/ Laptop Operating Systems } \\
\text { - } & \text { Browser } \\
\text { - } & \text { Additional Downloads } \\
\end{array}$ \\
\hline Mobile Design & $\begin{array}{ll}- & \text { Access } \\
- & \text { Functionality } \\
\text { - } & \text { Offline Access } \\
\end{array}$ \\
\hline $\begin{array}{l}\text { Privacy, Data } \\
\text { Protection, and } \\
\text { Rights }\end{array}$ & $\begin{array}{ll}\text { - } & \text { Sign Up/ Sign In } \\
\text { - } & \text { Data Privacy and Ownership } \\
\text { - } & \text { Archiving, Saving, and Exporting } \\
\text { Data }\end{array}$ \\
\hline $\begin{array}{l}\text { Social } \\
\text { Presence }\end{array}$ & $\begin{array}{ll}\text { - } & \text { Collaboration } \\
\text { - } & \text { User Accountability } \\
\text { - } & \text { Diffusion } \\
\end{array}$ \\
\hline $\begin{array}{l}\text { Teaching } \\
\text { Presence }\end{array}$ & $\begin{array}{ll}\text { - } & \text { Facilitation } \\
\text { - } & \text { Customization } \\
\text { - } & \text { Learning Analytics } \\
\end{array}$ \\
\hline $\begin{array}{l}\text { Cognitive } \\
\text { Presence }\end{array}$ & $\begin{array}{ll}\text { - } & \text { Enhancement of Cognitive Task(s) } \\
\text { - } & \text { Higher-Order Thinking } \\
\text { - } & \text { Metacognitive Engagement }\end{array}$ \\
\hline
\end{tabular}




\section{ANALYSIS AND DISCUSSION OF STUDY}

The interpretation of mean scores for this study was based on [17], as described in Table 2. The mean score and comprehensive analysis of e-learning tools evaluation among the students are described in the following sections.

Table 2: Interpretation of Mean Scores

\begin{tabular}{|c|c|c|}
\hline & Level & Mean \\
\hline 1 & Very low & $1.00-1.80$ \\
\hline 2 & Low & $1.81-2.60$ \\
\hline 3 & Moderate & $2.61-3.40$ \\
\hline 4 & High & $3.41-4.20$ \\
\hline 5 & Very High & $4.21-5.00$ \\
\hline
\end{tabular}

\subsection{Functionality}

In this category, functionality acknowledges a tool's processes and the condition or appropriateness of these functions to the designed plan.

Table 3 informs the students' perspectives on the functionality of Google Classroom as a tool for online learning. It shows that the highest mean value is 4.00 for the criteria:"The tool can be scaled to accommodate any size class with the flexibility to create smaller sub-groups or communities of practice." Meanwhile, the second highest mean score is 3.91, for the criteria: "The tool has a user-friendly interface", and "it is easy for instructors and students to become skillful within a personalized and intuitive manner". The findings suggest that Google Classroom requires less computer and IT skills from the students than other LMS. Students' satisfaction of LMS may influence student's behavioral intentions towards the use of e-learning tools $[18,19]$.

Table 3: Functionality of e-learning

\begin{tabular}{|c|c|c|c|c|}
\hline Category & Criteria & Mean & $\begin{array}{l}\text { Standard } \\
\text { Deviation }\end{array}$ & $\begin{array}{c}\text { Interpreta } \\
\text { tion }\end{array}$ \\
\hline \multirow{3}{*}{ 突 } & $\begin{array}{l}\text { Scale:The tool can be scaled } \\
\text { to accommodate any size } \\
\text { class with the flexibility to } \\
\text { create smaller sub-groups or } \\
\text { communities of practice. }\end{array}$ & 4.00 & 0.00 & High \\
\hline & $\begin{array}{l}\text { Ease of Use: The tool has a } \\
\text { user-friendlyinterface and it } \\
\text { is easy forinstructors and } \\
\text { students to } \\
\text { become skillful within } \\
\text { apersonalized and intuitive } \\
\text { Manner. }\end{array}$ & 3.91 & 0.42 & High \\
\hline & $\begin{array}{l}\text { Technical Support / Help } \\
\text { Availability: Campus-based } \\
\text { technical } \\
\text { support and /or } \\
\text { helpdocumentation is } \\
\text { readilyavailable and aids } \\
\text { users in } \\
\text { troubleshooting tasks or } \\
\begin{array}{l}\text { solvingproblems } \\
\text { experienced; or, thetool } \\
\text { provider offers a } \\
\text { robustsupport platform. }\end{array}\end{array}$ & 3.95 & 0.21 & High \\
\hline Overall Sc & & 3.95 & 0.21 & High \\
\hline
\end{tabular}

\subsection{Accessibility}

Universal Design by Learning (UDL) stated that for various learning methods and engagement for all students, the e-learning tool required flexible and adaptable curriculum design[16]. Therefore, there are some authoritative terms for reaching the precise accessibility requirements of learners with limitations.

Table 4 shows the highest mean score for the category of accessibility is 3.64 for the criteria of "required equipment". The majority of the students commented that the Google Classroom does not require special equipment. This finding suggests that accessibility to LMS with simple equipment enhances the students' online learning experience. The finding is consistent with previous investigation [20] that concluded accessibility to LMS improves the effectiveness of the e-learning tool.

The lowest mean in this category is the criteria "the cost of use" with mean 3.50. The finding reflects the limited access to the Internet for the majority of the students living far from the city and internet coverage. Previous studies discovered that the Google Classroom requires lower data consumption than other LMS. Previous investigation [25] concluded that the biggest challenge with distance education is the restrictions on internet communication, which may affect the accessibility of e-learning. To cope with this problem, teachers, educational institutions, and government need to collaborate in providing a LMS with the lowest cost internet consumption. As discussed in [21] efficient e-learning can be practiced by improving the lower factors for better results.

Table 4:Evaluation result based on Accessibility

\begin{tabular}{|c|c|c|c|c|}
\hline Category & Criteria & Mean & $\begin{array}{l}\text { Standard } \\
\text { Deviation }\end{array}$ & Interpretation \\
\hline \multirow[b]{2}{*}{ 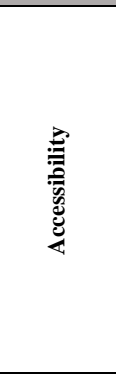 } & $\begin{array}{l}\text { Cost of Use: All aspects of } \\
\text { the tool can be used free of } \\
\text { charge. }\end{array}$ & 3.50 & 0.84 & High \\
\hline & $\begin{array}{l}\text { Required Equipment: } \\
\text { Proper use of the tool does } \\
\text { not require equipment } \\
\text { beyond what is typically } \\
\text { available to instructors and } \\
\text { students (computer with } \\
\text { built-in speakers and } \\
\text { microphone, internet } \\
\text { connection, etc.) }\end{array}$ & 3.64 & 0.71 & High \\
\hline Overall Sce & & 3.57 & 0.78 & High \\
\hline
\end{tabular}

\subsection{Technical}

The effectiveness of a LMS depends on user's technology such as hardware, internet access, software, and computer availability. The category "Technical" is important in determining the effectiveness of a LMS.

Table 5 illustrates the "Technical" category. The highest mean for this category is the criteria "Desktop / Laptop Operating System" with 3.82. Technically every operating system should able to support e-learning tools, and an updated operating system should not influence the e-learning tools. 
The lowest mean score in this category is at 3.55 is for "additional download" criteria. The finding suggests that despite being free web/cloud-based LMS, the students perceived using Google Classroom requires additional software.

Table 5: Evaluation result based on the category of Technical

\begin{tabular}{clccc} 
Category & \multicolumn{1}{c}{ Criteria } & Mean & $\begin{array}{l}\text { Standard } \\
\text { Deviation }\end{array}$ & Interpretation \\
\hline & $\begin{array}{l}\text { Desktop / Laptop Operating } \\
\text { System: Users can effectively } \\
\text { utilize the tool with any } \\
\text { standard, up-to-date operating } \\
\text { system. }\end{array}$ & 3.82 & 0.49 & High \\
& $\begin{array}{l}\text { Browser: Users can effectively } \\
\text { utilize the tool with any } \\
\text { standard, up-to-date browser. }\end{array}$ & 3.73 & 0.54 & High \\
$\begin{array}{l}\text { Additional Download: Users } \\
\text { do not need to download } \\
\text { additional software or browser } \\
\text { extensions. }\end{array}$ & 3.55 & 0.78 & High \\
\hline Overall Score & & & High
\end{tabular}

\subsection{Mobile Design}

With the wide selection of mobile devices, instructional approaches, and instruments that deliver content using mobile technology will remain to expand and hence assure their evaluation category. Table 6 shows that for the mobile design category, "access"is an essential aspect of e-learning. This criterion has the highest mean at 3.77. The lowest mean is 3.59 for functionality, where the aspect is based on the different designs between mobile and desktop for Google Classroom interface. This is a crucial factor that helps to enhance students' experience with online learning. The majority of the students prefer using mobile phones than desktops/laptops as they are faster, reliable, and convenient. Increased support for mobile tools helps enhance the students' experience with online learning [22].

Table 6: Evaluation result based on the category of Mobile Design

\begin{tabular}{|c|c|c|c|c|}
\hline Category & Criteria & Mean & $\begin{array}{l}\text { Standard } \\
\text { Deviation }\end{array}$ & Interpretation \\
\hline .5: & $\begin{array}{l}\text { Access: The tool can be } \\
\text { accessed, either through the } \\
\text { download of an app or via a } \\
\text { mobile browser, regardless of } \\
\text { the mobile operating system } \\
\text { and device. The design of the } \\
\text { mobile tool fully takes into } \\
\text { consideration the constraints of } \\
\text { a smaller-sized screen. }\end{array}$ & 3.77 & 0.67 & High \\
\hline$\frac{0}{\frac{0}{0}}$ & $\begin{array}{l}\text { Functionality: There is little to } \\
\text { no functional difference } \\
\text { between the mobile and the } \\
\text { desktop version, regardless of } \\
\text { the device used to access it. No } \\
\text { difference in functionality } \\
\text { between apps designed for } \\
\text { different mobileoperating } \\
\text { systems. }\end{array}$ & 3.59 & 0.58 & High \\
\hline
\end{tabular}

\begin{tabular}{llll}
$\begin{array}{l}\text { Offline AccessOffers an } \\
\text { offline mode: Core features of } \\
\text { the tool can be accessed and } \\
\text { utilized even when offline, } \\
\text { maintaining functionality and } \\
\text { content. }\end{array}$ & 3.64 & 0.64 & High \\
\hline Overall Score & 3.67 & 0.63 & High
\end{tabular}

\subsection{Privacy, Data Protection, and Design}

E-learning tools has many advantages but with risks. The main concerns with LMS are matters pertaining to intellectual property (IP) and privacy of information.Table 7 shows that the highest mean for the category "Privacy, Data Protection and Design" is for the criteria of "Sign Up/ Sign In" at 3.82. This finding reflects the user-friendly feature of Google Classroom that is easy $\log$ in and immediate access. The lowest mean for this category is 3.32 for the criteria "Archiving, Saving, and Exporting Data". As Google Classroom connects to Google Drive, it is easy for students to access old files on Google Drive when compared to other LMS. However, with the students' limited experience of using Google tools, the students perceived "archiving, saving and exporting data" through Google Classroom to be challenging.

Table 7:Evaluation result based on the category of Privacy, Data Protection, and Rights

\begin{tabular}{|c|c|c|c|c|}
\hline Category & Criteria & Mean & $\begin{array}{l}\text { Standard } \\
\text { Deviation }\end{array}$ & Interpretation \\
\hline \multirow{3}{*}{ 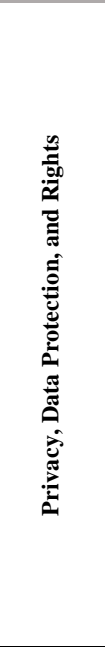 } & $\begin{array}{l}\text { Sign Up/ Sign In: Use of the } \\
\text { tool does not require } \\
\text { the creation of an external } \\
\text { Account or additional login, } \\
\text { such that no personal user } \\
\text { information is collected and } \\
\text { shared. }\end{array}$ & \multirow[t]{2}{*}{3.82} & 0.39 & High \\
\hline & $\begin{array}{l}\text { Data Privacy and } \\
\text { Ownership: Users maintain } \\
\text { ownership andcopyright of } \\
\text { their } \\
\text { intellectualproperty/data; the } \\
\text { user cankeep data private } \\
\text { and decide if/ how data is to } \\
\text { be shared. }\end{array}$ & & 1.02 & Moderate \\
\hline & $\begin{array}{l}\text { Archiving, Saving and } \\
\text { Exporting Data: Users can } \\
\text { archive, save, orimport and } \\
\text { export content oractivity } \\
\text { data in a variety of } \\
\text { Formats. }\end{array}$ & 3.32 & 0.92 & Moderate \\
\hline \multicolumn{2}{|c|}{ Overall Score } & 3.50 & 0.78 & High \\
\hline
\end{tabular}

\subsection{Social Presence}

This category examines the design of an online learning environments that design and foster a sense of community among the learners. The social presence is described as"the ability of participants to project their characteristics into the community, thereby presenting themselves to the other participants as real people"[23]. It concentrates on setting a secure, trustful context that raises collaboration and teamwork.

In this category, students' perspectives are sought on the ability of Google Classroom to encourage collaboration both asynchronous and synchronous. The mean score is at 3.77 as 
shown in Table 8. The finding suggests that the social presence is significant in Google Classroom. This finding is consistent with previous investigations that found Google Classroom as the primary collaborative e-learning tools [22], and the social presence is reliable for communication among the students (peer-interaction) and the teachers.

Table 8: Evaluation result based on the category of Social Presence

\begin{tabular}{clccc}
$\begin{array}{c}\text { Categor } \\
\mathbf{y}\end{array}$ & Criteria & Mean & $\begin{array}{c}\text { Standar } \\
\mathbf{d} \\
\text { Deviatio } \\
\mathbf{n}\end{array}$ & $\begin{array}{c}\text { Interpretatio } \\
\mathbf{n}\end{array}$ \\
\hline & $\begin{array}{l}\text { Collaboration: The tool } \\
\text { cansupport a community } \\
\text { oflearning through } \\
\text { bothasynchronous } \\
\text { andsynchronousopportuniti } \\
\text { es for communication, } \\
\text { interactivity,and transfer of } \\
\text { meaningbetween users }\end{array}$ & 3.77 & 0.42 & High \\
& & & \\
\hline Overall Score & 3.77 & 0.42 & High
\end{tabular}

\subsection{Cognitive Presence}

The final category for analysis is the cognitive presence. Cognitive presence refers to "the process of inquiry that moves from problem definition to exploration of relevant content and ideas, integrating those ideas into a meaningful structure or solution" [16]. This category acknowledges a tool's ability to support students' cognitive engagement in learning tasks.

Table 9 shows in the "cognitive presence" category, the criteria on "metacognitive" shows the highest mean at 3.86 . This finding reflects the multifaceted feature of Google Classroom from collaborative e-learning tools, to obtaining immediate feedback from the teacher in real-time, real-time communication with their peers while working on tasks.

Table 9: Evaluation result based on the category of Cognitive

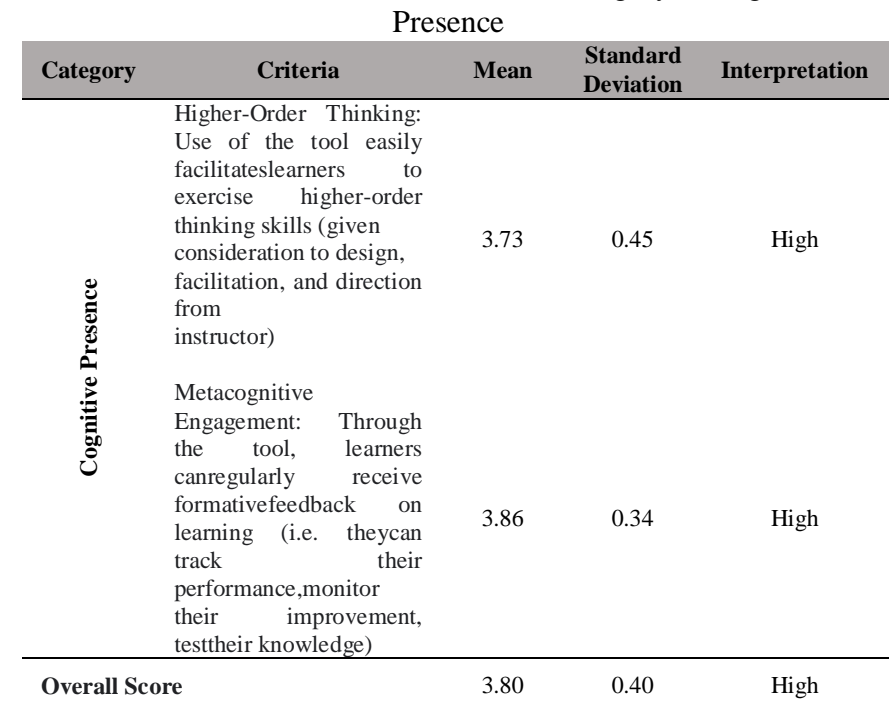

\subsection{Overview of the evaluation Google Classroom}

This section discusses the overview of the categories that were analyzed in the study. The categories included functionality, accessibility, technical, mobile design, privacy, data protection, and rights, social presence, and cognitive presence. Overall, the mean value for all categories isat 3.71 as presented in Table 10. The finding suggests that the students perceived Google Classroom as an effective tool for LMS. The findings revealed that utilization of Google Classroom as part of the online education positively impacts the students' learning experience. Previous investigation [24] commented that the categories and criteria for evaluation of LMS is not exhaustive to the rubric presented in Table 1. There may be other categories and criteria that may have been overlooked.

Table 10: Evaluation result for overall mean for eachcategory

\begin{tabular}{r|r} 
Category & Mean \\
Functionality & 3.95 \\
Accessibility & 3.57 \\
Technical & 3.70 \\
Mobile Design & 3.67 \\
Privacy, Data Protection & 3.50 \\
and Rights & \\
Social Presence & 3.77 \\
Cognitive Presence & 3.80 \\
\hline Overall & $\mathbf{3 . 7 1}$
\end{tabular}

\subsection{Interaction of Operating System for Google Classroom and Social Presence}

Table 11 summarizes the mean value obtained for the interaction of Operating Systems (OS) for Google Classroom and Social Presence is at $0.03(\sigma=0.05)$. This finding indicates that there is a significant interaction of OS for Google Classroom and Social Presence, thus rejecting the Null hypothesis (H0). The correlation between the OS and collaboration in Social Presence is low with R-value at 463 (significant at the 0.05). The relationship between these two constructs can be summarized as the lower the effectiveness of utilizing the tool with any standard and streamlined operating system, the higher the collaboration in social presence level achieve because the R-value was positive.

Table 11: Result of the relationship between the operating system used and social presence for collaboration

\begin{tabular}{ccccc}
\hline Variable & \multicolumn{2}{c}{ Operating System } & \multicolumn{2}{c}{$\begin{array}{c}\text { Collaboration } \\
\text { (Social Presence) }\end{array}$} \\
\cline { 2 - 5 } & $\mathrm{R}$ & Sig. & $\mathrm{R}$ & Sig. \\
\hline $\begin{array}{c}\text { Operating } \\
\text { System }\end{array}$ & 1 & & & \\
\hline $\begin{array}{c}\text { Collaboration } \\
\text { (Social Presence) }\end{array}$ & $.463^{*}$ & 0.030 & 1 & \\
\hline
\end{tabular}

\section{CONCLUSION}

This research was aimed to seek students' perspectives on the effectiveness of Google Classroom as a tool for online learning. In particular, the study aimed to evaluate the use 
Google Classroom utilizing rubric presented in Table 1. The study also studied the interaction of OS for Google Classroom and collaboration in Social Presence. The findings suggested the majority of the students perceived Google Classroom positively for its functionality, mobile design, technical, social and cognitive presence. Although Google Classroom is a free, web and cloud-based LMS with features and tools that support students' learning, the challenges the students faced with using Google Classroom are similar to those of the problems addressed with using Moodle (see section 2.3).

The challenges for the future in enhancing students' online learning experience is to increase the internet speed and coverage, training students to be skilled in IT, and consideration of other categories and aspects in the evaluation of LMS.

\section{ACKNOWLEDGEMENT}

The authors would like to thank Dhofar University and Universiti Pendidikan Sultan Idris for supporting this study.

\section{REFERENCES}

1. Zu, Z. Y., Jiang, M. D., Xu, P. P., Chen, W., Ni, Q. Q., Lu, G. M., \& Zhang, L. J. Coronavirus disease 2019 (COVID-19): a perspective from China. Radiology, vol. 296, no. 2, pp. 15-25, 2020.

https://doi.org/10.1148/radiol.2020200490

2. Qianying, L, Shi, Z., Daozhou, G., Yijun, L., Shu, Y., Salihu, S. M., Maggie, H. W., Yongli, C., Weiming, W., Lin, Y., Daihai, H.A conceptual model for the coronavirus disease 2019 (COVID-19) outbreak in Wuhan, China with individual reaction and governmental action, Int. Journal Infectious Diseases, vol. 93, pp. 211-216, April, 2020.

3. Kavaljit,

https://zcomm.org/znetarticle/how-to-manage

-the-economic-fallout-of-the-coronavirus/, March, 2020.

4. United Nations Educational, Scientific and Cultural Organization [UNESCO].1.37 billion students now home as COVID-19 school closures expand; ministers scale up multimedia approaches to ensure learning continuity. UNESCO. Retrieved March 24, 2020 from https://en.unesco.org/news/137-billion-students-now-ho me-covid-19-school-closures-expand-ministers-scale-m ultimedia

5. United Nations Educational, Scientific and Cultural Organization [UNESCO]. COVID-19 Impact on Education, Retrieved August 1, 2020, from https://en.unesco.org/covid19/educationresponse, 2020.

6. Soffer, T., \& Nachmias, R. Effectiveness of learning in online academic courses compared with face-to-face courses in higher education, J. Computer. Assist. Learn, vol. 34, no. 5, pp. 534-543, 2018.

7. Karthikeyan, J., Rajasekaran, W. C., \& Unyapho, P. Analysis of Diverse Open Source Digital Tools and Learning Management System Users in Academics, In: Satapathy S., Bhateja V., Somanah R., Yang XS.,
Senkerik R. (eds) Information Systems Design and Intelligent Applications. Advances in Intelligent Systems and Computing, Springer, Singapore, vol. 862, pp. 145-157, 2019.

8. Ishak, W. H. W., \& Yamin, F. M. Student Acceptance on Game to Support Teaching and Learning. International Journal of Advanced Trends in Computer Science and Engineering, vol. 9, no.3, pp. 2517-2521, 2020.

https://doi.org/10.30534/ijatcse/2020/05932020

9. Dey, A., \& Roy, N. R. Confluence of ICT Based Education and Teacher Preparation: Need of the Hour, IJRAR-International Journal of Research and Analytical Reviews, vol. 6, pp. 2348-1269, 2019.

10. Zulkefli, N. A. M., Hashim, H., Ismail, A., Jamaluddin, J. Effects of using Virtual Learning Environment in Teaching and Learning Malay Language, The Int. Journal of Multimedia \& Its Applications (IJMA), vol. 10, no. 6, pp. 14-29, December 2018.

11. Muljana, P. S., \& Luo, T. Factors contributing to student retention in online learning and recommended strategies for improvement: A systematic literature review,Journal of Information Technology Education: Research, vol. 18,pp. 19-57, 2019.

https://doi.org/10.28945/4182

12. Vaganova, O. I., Smirnova, Z. V., Vezetiu, E. V., Kutepov, M. M., \& Chelnokova, E. A. Assessment tools in e-learning Moodle, International Journal of Advanced Trends in Computer Science and Engineering, vol. 9, no.3, pp. 2488-2492, 2020.

https://doi.org/10.30534/ijatcse/2020/01932020

13. Alia, S., \& Hamtini, T. Designing and Implementing an e-Course Using Adobe Captivate and Google Classroom: A Case Study. In 2019 2nd International Conference on new Trends in Computing Sciences (ICTCS), 2019, pp. 1-6.

14. Ramadhani, R., Umam, R., Abdurrahman, A., \& Syazali, $M$. The effect of flipped-problem based learning model integrated with LMS-google classroom for senior high school students, Journal for the Education of Gifted Young Scientists, vol. 7, no. 2, pp. 137-158, 2019.

15. Rachel G. \& Collin S. Teaching with tech, Rebooting the traditional. https://www.moundsviewschools .org/site/handlers/filedownload.ashx?

moduleinstanceid $=8224 \&$ dataid $=7973 \&$ FileName $=$ Scho olTalkSpring2015.pdf, 2015

16. Anstey, L., \& Watson, G. A rubric for evaluating e-learning tools in higher education, EDUCAUSE Review, 2018.

17. Hamzah, M., Juraime, F. and Mansor, A. Malaysian Principals' Technology Leadership Practices and Curriculum Management. Creative Education, vol. 7, pp. 922-930, 2016.

18. Theresiawati, T., Seta, H. B., Hidayanto, A. N., \& Abidin. Z. Variables affecting e-learning services quality in Indonesian higher education: Students' perspectives. Journal of Information Technology Education:Research,vol.19, pp. 259-286, 2020. 
19. Liaw, S. S. Investigating students' perceived satisfaction, behavioral intention, and effectiveness of e-learning: A case study of the Blackboard system. Computer \& Education, vol. 51, no. 2, pp. 864-873, 2008. https://doi.org/10.1016/j.compedu.2007.09.005

20. Al Hamad. Q. M. Acceptance of E-learning among university students in UAE: A practical study,

International Journal of Electrical and Computer Engineering (IJECE), vol. 10, No. 4, pp. 3660-3671, 2020.

21. Al Kurdi, B., Alshurideh, M., \& Salloum, S. A. Investigating a theoretical framework for e-learning technology acceptance, International Journal of Electrical and Computer Engineering (IJECE), vol.10, no.6, pp. 6484-6496, 2020.

22. Syafi'i, A. Google Classroom as Learning Platform In Teaching Writing. British (Jurnal Bahasa dan Sastra Inggris), vol. 9, no.1, pp. 48-64, 2020.

23. Garrison, D. R. E-learning in the 21st century: A framework for research and practice, Taylor \& Francis, 2011.

24. Lee, J. E., Recker, M., \& Yuan, M. The Validity and Instructional Value of a Rubric for Evaluating Online Course Quality: An Empirical Study, Online Learning, vol. 24, no. 1, pp. 245-263, 2020.

25. Shtukareva, E. B., Sergeeva, S., Zolotukhina, Y., Orlyuk, A., \& Kopylov, I. A. Internet Communications in the Context of Restrictions on Population Mobility. International Journal of Advanced Trends in Computer Science and Engineering, vol. 9, no. 3, pp. 3904-3909, 2020.

https://doi.org/10.30534/ijatcse/2020/211932020 